\title{
ARTIKULASI ILMU NAHWU DALAM KEHIDUPAN (Studi Analisis Makna I'rob Kitab Al-Jurumiyah Menggunakan Semantika Dalalah Lafzhiyah dalam Ushul Fikih)
}

\author{
Oleh: Ahmad ${ }^{1}$ \\ Email: ahjelly@gmail.com
}

\begin{abstract}
In the environment of the Islamic Boarding School Nahwu the basis for the scientific foundation of Islam. The Nahwu book that is often used by almost the majority of Islamic boarding schools is al-Ajurumiyah (read; Jurumiyah). In the discussion of this jurumiyah book there is a discussion about I'rob, namely a discussion of changes in a sentence caused by changes in 'amil (factors) that affect it. This study uses the semantics of language research methods using lafzhiyyah dalalah contained in ushul figh. The purpose of this study is to uncover the scope of the articulation of a language that can be interpreted in a broader meaning, not only in the grammatical meaning of language, but also in the meaning of life. The analysis technique of this research uses interpretive techniques, namely researchers interpreting the object of discussion and research using theoretical studies used according to the researcher perspective. The results of this study reveal that I'rob can be articulated in the meaning of daily life, along with its I'rob signs. I'rob jazm means constant and silent which has the sign of I'rob breadfruit (silence); meaning someone who is just silent, stand by (breadfruit/silent) then the position will be stagnant. I'rob khofazh (low, Jar; attractive) means low has the sign of I'rob kasroh (breaking, damaging), meaning that someone whose job is identical to damaging and breaking then his position will be in a low position (bottom). I'rob nashob means the same, standard, flat which has the sign of fathah (opening); it means someone who has the behavior of fathah (opening) then the position will be the same, equal to the average person. I'rob rofa 'means height, fly, lost has the sign I'rob dlommah (proclaim); meaning someone who wishes to be in the position of rofa '(high and fly) then he must have the behavior of dlommah; namely the behavior of gathering, gathering knowledge, gathering friends, relationships, cooperation, followers, including collecting assets and positions. Thus, a person can have a high degree.
\end{abstract}

Keywords: nahwu, analysis, meaning

${ }^{1}$ Dosen Prodi Hukum Pidana Islam STAI Syaichona Moh. Cholil Bangkalan 


\section{Pendahuluan}

Pesantren adalah tempat sekaligus lingkungan yang menyelenggarakan pendidikan Islam. Pendidikan Islam di pesantren dikenal dengan istilah kajian kitab kuning. Kajian kitab kuning adalah sebuah kajian keilmuan yang menggunakan media kitab dan literatur berbahasa Arab, mulai dari dasar, menengah hingga tingkat tinggi. Kajian kitab kuning paling dasar yang akan ditempuh oleh seorang santri adalah kajian tentang ilmu alat, yaitu ilmu yang mempelajari tentang cara memahami gramatika bahasa Arab. Kajian kitab kuning ilmu alat atau gramatika bahasa Arab ini terdiri dari ilmu nahwu dan ilmu shorrof.

Kajian ilmu nahwu dan ilmu shorrof -selain ilmu-ilmu lainnyadianggap sebagai pengantar dan pondasi bagi keilmuan seorang santri, disebutkan bahwa ilmu nahwu adalah bapak dari segala ilmu, sementara shorrof adalah ibunya ${ }^{2}$. Ilmu nahwu juga disebutkan sebagai ilmu paling dasar yang harus diketahui oleh seorang calon sarjana dan ilmuan muslim ${ }^{3}$. Syaikh Imrithi mensyiarkan pentingnya belajar ilmu dalam sebuah langgam:

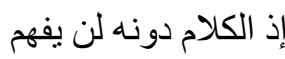
والنحو أولى أو لا أن بعلم

Salah satu kitab dasar ilmu nahwu yang dipelajari di pesantren adalah kitab al-Ajurumiyah atau Jurumiyah (bahasa Arab: الآجُرُوبِيَّة). Kitab Jurumiyah adalah sebuah kitab kecil tentang tata bahasa Arab dari abad ke-7 H/13 M. kitab ini berisi tentang rumus-rumus dasar pelajaran bahasa Arab klasik ditulis dengan bentuk berima untuk memudahkan dalam menghafal.

Kitab ini disusun oleh ahli bahasa dari Maroko yaitu Abu Abdillah Muhammad bin Muhammad bin Dawud Ash Shinhaji (kadang disebut Ash Shonhaji), yang lebih dikenal dengan nama Ibnu Ajurum. Nisbah beliau Ash Shinhaji, merupakan nisbah kepada qabilah Shinhajah di daerah

\footnotetext{
2 Makalah terkenal dengan redaksi النحو أبو العلم والصرف أمها

3 Syaikh Syafifuddin Yahya al-Imrithy. Nazham al-Jurumiyah al-Imrithy. Maktabah Syamilah (Kitab Digital). Juz 1 hlm 1.
} 
Maghrib. Beliau dikenal dengan nama Ibnu Ajurum. Ajurum artinya orang yang fakir dan seorang shufi.

Ibnu Ajurum dilahirkan di kota Fas, sebuah daerah yang besar di Negeri Maghrib pada tahun $672 \mathrm{H}$. Pada tahun itu pula seorang pakar nahwu yang terkenal yaitu pengarang Kitab Alfiyah yang bernama Ibnu Malik meninggal dunia. Ibnu Ajurum wafat di Fas pada hari Senin, tanggal 10 Safar $723 \mathrm{H}^{4}$.

Awalnya, Ibnu Ajurum belajar di Fas, kemudian beliau berangkat haji ke Makkah. Ketika melewati Kairo, beliau belajar nahwu kepada Abu Hayyan, salah seorang pakar nahwu negeri Andalusia, penyusun Kitab al Bahrul Muhith, sampai beliau mendapatkan ijazah (rekomendasi) dari Abu Hayyan.

Ibnu Ajurum menyusun Matan Al Ajurumiyah pada tahun $719 \mathrm{H}$, empat tahun sebelum beliau wafat. Ibnu Maktum yang sezaman dengan Ibnu Ajurum -setelah memuji Ibnu Ajurum- menyebutkan di dalam Tadzkirahnya bahwa pada saat dia menulis tadzkirah tersebut, Ibnu Ajurum masih hidup.

Ar Ra'i dan Ibnul Haj menyebutkan bahwa Ibnu Ajurum menulis kitab ini di hadapan Ka'bah. Ditambahkan oleh Al Hamidi bahwa setelah menulis kitab ini, Ibnu Ajurum membuang kitabnya ke laut sambil berkata, "Kalau memang kitab ini kutulis ikhlas karena Allah, maka niscaya kitab ini tidak akan basah." Ternyata kitab Al Ajurumiyah yang beliau tulis tidak basah. Sehingga walaupun kitab ini tipis dan ditujukan bagi pemula, namun karya tulis beliau ini diterima oleh semua kalangan ${ }^{5}$.

Dalam ilmu gramatika bahasa Arab, ilmu nahwu digunakan sebagai panduan untuk menentukan bacaan pada akhir kalimat. Sementara ilmu shorrof dipakai untuk menentukan bacaan perhuruf dalam kalimat.

Dalam konteks keseharian, bahwa bahasa merupakan sarana artikulasi yang ditampilkan oleh manusia untuk mengungkapkan apa yang

4 Abu Abdillah Muhammad bin Muhammad bin Dawud Ash Shinhaji. Matn alAjurumiyah. Maktabah Syamilah (kitab digital). Juz 1 hlm 1.

${ }^{5}$ Ibid. Matn al-Ajurumiyah. Maktabah Syamilah (kitab digital). Juz 1 hlm 1. 
dipikirkan sesuai dengan isi hatinya ${ }^{6}$. Apa yang diungkapkan oleh manusia melalui bahasa akhirnya menjadi realitas kehidupan yang dijalaninya. Dengan demikian, terdapat interrelasi apa yang ada dalam bahasa dan apa yang menjadi kenyataan manusia. Artikulasi makna i'rob dalam kehidupan sehari-hari merupakan artikulasi dari adanya interrelasi ini. I'rob dalam gramatika bahasa Arab yang berarti perubahan akhir dari sebuah kalimat dengan perubahan yang terjadi dalam kehidupan manusia. Penelitian ini akan meneliti tentang artikulasi interralasi makna i'rob dalam gramatika bahasa dalam kehidupan sehari-hari menggunakan dalalah lafzhiyyah dalam ushul fikih.

\section{Kajian Teori}

Dalam ushul fikih, pembahasan tentang dalalah lafzhiyyah sangat penting. Pembahasan tentang dalalah lafzhiyyah dijelaskan setelah pembahasan tentang hukum ${ }^{7}$. Pembahasan tentang dalalah lafzhiyah berkelindan seputar lafazh dan makna yang lahir dari bahasa manusia. Bahasa adalah lafazh-lafazh yang menunjukkan pada makna-makna. Bahasa diperoleh dari transfer (dari orang tua/ masyarakat) dan juga diperoleh melalui pemikiran. 8

Madlul (yang ditunjuki) lafazh dapat berupa:

\section{a. Makna}

1. Juziy ${ }^{9}$

2. Kully ${ }^{10}$

b. Lafazh

1. Mufrad

a. Musta'mal (dipakai)

\footnotetext{
6 Syaikh Zakariya bin Muhammad bin Ahmad bin Zakariya al-Anshori. Ghayatul Wushul . Maktabah Syamilah (kitab digital). Juz 1 hlm 27.

${ }^{7}$ Ibid. Ghayatul Wushul. Maktabah Syamilah (kitab digital). Juz 1 hlm 27.

${ }^{8}$ Kiranya bahasa tidak hanya tertentu pada bahasa lisan saja. Lebih jauh bahasa juga berkembang melalui bantuan teknologi. Terbukti dengan penemuan bahasa ilmu pengetahuan yang sekarang sedang berkembang, seperti bahasa computer.

${ }_{9}^{9}$ Adalah makna yang tidak dapat dimiliki bersama (e kadibi'i). Seperti madlul lafazh زيد ${ }^{10}$ Adalah makna yang dapat dimiliki bersama (e karobuti). Seperti madlul lafazh الإنسان . Makna lafazh ini mencakup terhadap semua orang.
} 
b. Muhmal (tidak dipakai)

\section{Murakkab}

a. Musta'mal (dipakai)

b. Muhmal (tidak dipakai)

Wadl' adalah menjadikan lafazh sebagai dalil sebuah makna, walaupun lafazh tersebut tidak selaras dengan maknanya. Lafazh diwadla' kan untuk makna dalam pikiran. Muhkam adalah lafazh yang telah jelas maknanya (bisa berupa nash dan dhahir). Tidak setiap makna mempunyai lafazh, akan tetapi lafazh baru diberikan untuk makna yang membutuhkan lafazh (sebagai sarana untuk aktualisasi diri agar dapat dimengerti).

Sedangkan mutasyabih adalah lafazh yang masih belum jelas maknanya. Akan tetapi kadang-kadang Allah menjelaskan makna lafazh mutasyabih kepada orang-orang pilihannya. Lafazh yang umum tidak boleh dimaknai dengan makna khofi untuk kalangan awam (akan tetapi lafazh tersebut harus dimaknai dengan makna dhahirnya). Seperti perkataan orang yang menetapkan keadaan "التحرك (bergerak) adalah makna yang menyebabkan adanya gerakan zat. ${ }^{11}$

Bahasa merupakan masalah taukify; anugerah Allah yang diajarkan kepada hamba-hambanya melalui wahyu, atau juga bisa melalui penciptaan suara, dan atau juga pengetahuan yang sifatnya dharuriy (tanpa belajar manusia mengetahui dengan sendirinya). Sesuatu yang sifatnya taukify, dalilnya masih dzanniy (diragukan). Lafazh yang maknanya mengandung sifat persamaan tidak dapat diqiyaskan dengan lafazh lain.12

Mantuq adalah makna yang ditunjukkan lafazh, (yang) makna tersebut berada dalam ucapan (lafazh). Lafazh yang menunjukkan pada

\footnotetext{
11 Lafazh ini tidak dimaknai dengan makna khofi sehingga bermakna "makna yang mewajibkan adanya sebuah gerakan". Makna ini dianggap terlalu sulit untuk kalangan awam (khofi), untuk lebih mudahnya lafazh ini cukup dimaknai dengan makna dhohirnya saja yaitu bergeraknya benda

12 Seperti lafazh khamr. Khamr adalah sebuah nama bagi sesuatu yang dapat memabukkan yang terbuat dari perasan anggur. Sesuatu yang dapat memabukkan ini tidak hanya dapat dibuat dari perasan kurma saja, akan tetapi dari perasan anggur, tape dan lain walaupun demikian secara bahasa perasaan anggur tidak dapat dikatakan khamr. (Lain halnya dengan pendapat yang mengatakan bahwa qiyas secara bahasa boleh-boleh saja dilakukan)
} 
makna yang tidak memungkinkan untuk dipahami makna lain, seperti lafazh ${ }^{13}$ j disebut nash. Lafazh yang menunjukkan pada makna yang masih mempunyai kemungkinan untuk dimaknai lain, seperti lafazh اسد 14 disebut zhahir ${ }^{15}$. Lafazh yang juz lafazhnya menunjukkan pada juz maknanya disebut murakkab. ${ }^{16}$ Dan jika tidak ${ }^{17}$, maka disebut mufrad.

Dalalah (penunjukan) lafazh pada makna secara langsung disebut dalalah muthabaqah. Dalalah lafazh pada juz maknanya disebut dalalah tadlammun. Dalalah lafazh pada makna lazim ${ }^{18}$ yang tergambar di pikiran

${ }^{13}$ lafazh ini hanya menunjuk pada seseorang yang bernama Zaid, tidak yang lain

14 Lafazh ini menunjukkan pada makna yaitu harimau, namun lafazh ini masih mempunyai kemungkinan untuk dimaknai makna yang lain yaitu lelaki pemberani. Makna pertama disebut hakekat sedangkan makna kedua disebut majaz. Makna pertama disebut makna dhahir (jelas) sedangkan makna kedua disebut makna khafiy (samar). Makna pertama disebut makna rajih (unggul) sedangkan makna kedua disebut makna marjuh

15 Selain zhahir ada satu lafazh lagi yaitu Mujmal. Mujmal adalah lafadz yang menunjukkan pada dua makna dengan kemungkinan yang sama untuk dipilih salah satunya, tidak ada yang menang, dan tidak ada pula yang kalah. Kedua makna dalam kedudukannya sama-sama hakekat Seperti lafadz بَوْن (belang). Lafadz ini menunjukkan pada makna hitam dan putih sama besarnya

16 Dalam lafazh ini setidaknya terkandung dua syarat. Pertama, lafazh tersebut mempunyai juz. Kedua, juz lafazh tersebut menunjukkan pada makna juz lafazh tersebut sendiri. Contoh lafazh ini adalah غنام زيد . Lafazh ini mempunyai juz yaitu

غالامdan زيد . Juz lafazh ini menunjukkan pada maknanya sendiri-sendiri, yaitu budak dan zaid, sehinnga bermakna budak yang dimiliki Zaid. Ketika lafazh ini diucapkan ada dua orang yang terbayang dalam benak orang yang mendengarnya yaitu majikan dan budak

${ }^{17}$ Kemungkinan lafazh mufrad bisa berarti

a. Memang tak punya juz seperti hamzah istifham,

b. Punya juz tapi tidak punya makna seperti huruf-huruf yang terdapat dalam berupa s

c. Punya juz tapi tidak menunjukkan pada makna juznya secara mandiri, seperti lafazh yang telah menjadi nama, عبد الله Lafazh ini memang mempunyai juz yaitu عبد dan ال山 . Tapi juz lafazh ini tidak menunjukkan pada makna juznya secara mandiri. Lafazh ini menunjukkan pada orang yang bernama Abdullah

18 Makna lazim dapat dijelaskan dengan ilustrasi berikut ini. Ada sebuah lafadz menunjukkan pada makna I, makna I ini menunjukkan pada makna II. Nah, penunjukan lafadz pada makna II inilah disebut makna lazim. Makna I pasti menunjukkan pada makna II, satu sama lain tidak dapat dipisahkan. 
disebut dalalah. Dua dalalah pertama (muthabaqah dan tadlammun) adalah dalalah lafzhiyah. Sedangkan dalalah yang terakhir adalah dalalah 'aqliyah.

Kemudian (dalalah iltizam dibagi menjadi;) jika dalalah iltizam yang kebenaran atau keshahihan makna mantuqnya masih menunggu pada penyimpanan (kalimat lain) disebut dengan Iqtidla' . (Dalalah iltizam) yang lafazhnya menunjuk pada makna yang tidak dimaksud oleh lafazh itu sendiri disebut dalalah isyarah. ${ }^{19}$ Dan jika (dalalah iltizam) tidak (seperti di atas; ${ }^{20}$ ) disebut dengan dalalah ima'.

Mafhum adalah makna yang ditunjukkan lafazh, yang makna tersebut tidak berada dalam ucapan (lafazh). Jika makna mafhumnya selaras dengan makna mantuqnya disebut muwafaqah walaupun menyamai. Lalu disebut mafhum muwafaqah Fahwa al-Khitab jika tingkat keselarasannya lebih utama/tinggi dari makna mantuqnya. ${ }^{21}$ Dan disebut mafhum muwafaqah Lahn al-Khitab jika tingkat keselarasannya sederajat/sama dengan makna mantuqnya. ${ }^{22}$

Dalalah lafazh yang terdapat dalam mafhum muwafaqah adalah dalalah secara mafhumiyah. Jika makna mafhumnya berkebalikan dengan mantuqnya disebut dengan mafhum mukhalafah. Syarat lafazh dapat diambil mafhum mukhalafahnya; lafazh tersebut harus dapat memunculkan mafhum mukhalafah (karena ada lafazh yang tidak dapat diambil mafhum mukhalafahnya).

Lafazh tidak bisa diambil mafhum mukhalafah jika dalam kondisi lafazh tersebut menunjukkan makna yang keluar dari kebiasaan (lafazh tersebut diucapkan hanya untuk menjelaskan kebiasaan yang berlaku pada masyarakat itu). (Orang yang mengucapkan lafazh tersebut) karena berada dalam keadaan tertekan, atau lafazh tersebut hanya untuk menjelaskan kenyataan (yang terjadi ketika lafazh itu disampaikan). Atau lafazh tersebut

19 Lafazh menunjukkan pada makna I, makna I menunjukkan pada makna II. Nah, dalalah lafazh pada makna II inilah yang disebut dengan dalalah Isyarah

${ }^{20}$ dalalah lafazh tidak menunjuk pada makna yang tidak dimaksud, dan juga dalalah lafazh ini tidak membutuhkan penyimpanan

${ }^{21}$ Contoh keharaman memukul kedua orang dari ayat yang melarang kita berkata Ah ! kepada kedua orang tua

${ }^{22}$ Contoh keharaman mengahabiskan harta anak yatim yang diperoleh dari ayat yang berisi larangan memakan harta anak yatim 
muncul karena ada pertanyaan atau (menjelaskan) kejadian. Atau lafazh tersebut muncul karena tidak mengetahui hukum yang dikandung mantuq atau mafhum. Boleh-boleh saja menganalogikan (mengqiyaskan) apa yant tidak ucapkan (mafhum) dengan mantuq. Oleh karena itulah, apa yang singgun-singgung (dalam mafhum) tidak mencakup pada apa yang tidak disebutkan.

Mafhum mukhalafah adalah mafhum sifat ${ }^{23}$, seperti (mukhalafah sifat) yang terdapat dalam contoh-contoh berikut.

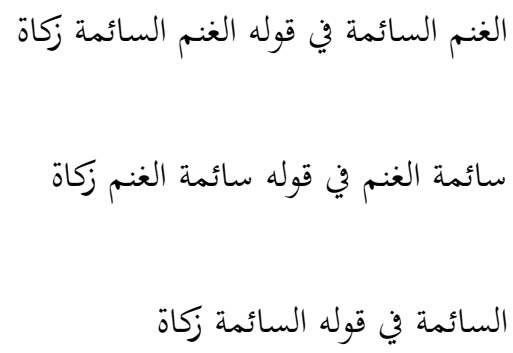

Yang dinafikan (tidak wajib zakat) pada contoh pertama dan kedua adalah kambing yang diberi makan. Sedang pada pada contoh yang ketiga, yang dinafikan adalah hewan ternak yang diberi makan. ${ }^{24}$

Termasuk dalam mafhum mukhalafah sifat adalah 'illat, dzaraf, hal, syarat, ghayah, mendahulukan ma'mul (ikhtishash) dan 'adad. إنما، ضمير الفصل،لا، إلا dapat berfaedah Hasr. Mafhum mukhalafah merupakan hujjah pengambilan hukum, secara bahasa laqab tidak termasuk mafhum mukhalafah.

\section{Metodologi}

Penelitian ini menggunakan pendekatan semantik leksikal. Semantik leksikal adalah kajian semantik yang lebih mengutamakan pada

\footnotetext{
23 Sifat adalah lafadz yang dapat memberikan "qayyid -catatan- terhadap lafadz lain".

24 Mafhum mukhalafah sifat dari contoh 1 dan 2 ini adalah kambing yang diberi makan, sehingga yang tidak wajib dizakati adalah hanya kambing yang diberi makan. Sedang hewan ternak selain kambing yang diberi makan, wajib dizakati. Sedang pada contoh ketiga, Mafhum mukhalafah sifat berlaku untuk semua hewan ternak yang diberi makan, sehingga yang tidak wajib dizakati adalah semua hewan ternak yang diberi makan.
} 
pembahasan sistem makna yang terdapat dalam kata. Kajian semantik leksikal ini dalam teori ushul fikih dikenal dengan kajian dalalah lafzhiyah. Dalalah lafzhiyah dalam kajian ushul fikih memuat tentang kajian secara kebahasaan tentang lafazh dan makna.

Untuk mendukung pendekatan semantik leksikal tersebut, peneliti menggunakan metode deskriptif kualitatif. Metode deskriptif kualitatif adalah metode penelitian yang dilakukan semata-mata berdasarkan fakta kebahasaan yang ada atau fenomena yang secara empiris hidup pada penuturnya. Peneliti menggunakan metode deskriptif kualitatif karena peneliti dapat mengklasifikasikan serta mendeskripsikan hal-hal yang berhubungan dengan verba berendonim berbicara. Penelitian ini dilakukan dengan menganalisis data yang ada tanpa menambah atau mengurangi sesuai dengan sifat data yang alamiah, data yang dianalisis diuraikan dalam bentuk kata-kata berdasarkan data di lapangan.

Sumber primer dalam penelitian ini adalah sumber data yang langsung memberikan data kepada pengumpul data, yaitu al-Qur'an, Hadits, dan kitab-kitab nahwu, penelitian baik dalam bentuk jurnal, tesis ataupun disertasi. Sumber sekunder dalam penelitian ini adalah sumber yang tidak langsung memberikan data kepada pengumpul data yaitu datadata pendukung seperti buku-buku tentang al-Qur'an, Hadits dan lainnya.

Adapun metode pengumpulan data yang digunakan dalam penelitian ini adalah dengan studi dokumentasi, yaitu teknik yang digunakan dengan cara mencari, menganalisis, membaca tulisan dan bukubuku yang didasarkan pada tulisan-tulisan terbaru dari beberapa ahli serta mencangkup hasil pemikiran dan ide yang telah ditulis oleh pemikirpemikir dan ahli-ahli. Pengecekan keabsahan data juga dilakukan dengan obsevasi yang diperdalam, triangulasi (menggunakan beberapa sumber, metode, peneliti, teori), serta melakukan diskusi yang lebih intensif dengan teman / ahli yang memiliki otoritas dalam penyusunan penelitian.

Dalam penulisan ini, setelah data diperoleh, kemudian dianalisis dengan menggunakan teknik interpretatif; yaitu menggunakan jenis penafsiran menurut peneliti menggunakan metode dalalah lafzhiyyah yang terdapat dalam teori ushul fikih. 
Interpretasi yang peneliti lakukan diuraikan dalam langkah-langkah sebagai berikut.

a. Menjelaskan redaksi kalimat dari kitab al-Jurumiyah;

b. Menguraikan artikulasi redaksi kalimat dari kitab al-Jurumiyah tersebut;

c. Menafsirkan artikulasi redaksi kalimat dari kitab al-Jurumiyah tersebut.

\section{Pembahasan}

Pembahasan tentang i'rob dalam kitab al-Jurumiyah berada pada bab kedua, setelah pembahasan tentang pengantar kalimat. Berikut adalah redaksi pembahasan tentang i'rob. Pemaknaan secara semantika leksikal menggunakan dalalah lafzhiyyah terhadap pembahasan i'rob dapat diuraikan dengan pendekatan makna mantuq dan mafhum.

Pemaknaan secara mantuq dapat diperoleh dengan adanya kemungkinan-kemungkinan makna yang dimiliki oleh sebuah lafazh. Dalam hal ini, i'rob dalam pemaknaan mantuq selain dipahami sebagai pemaknaan secara gramatikal bahasa Arab yang berarti perubahan sebuah kalimat disebabkan oleh perbedaan amil yang masuk di dalamnya. Selain pemaknaan dalam konteks mantuq gramatika bahasa Arab ini, i'rob dapat dimaknai dengan sebuah makna perubahan yang terjadi bagi sebuah manusia (dalam bentuk perubahan status dan kondisi) berdasarkan faktorfaktor yang mempengaruhi perubahan tersebut.

Sementara pemaknaan secara mafhum diperoleh dengan kemungkinan pemaknaan yang dapat diinterpretasikan dalam makna kehidupan sehari-hari sesuai dengan mantuq i'rob itu sendiri. Hal ini didasarkan atas definisi dari mafhum sendiri yaitu sebuah makna yang ditunjukkan oleh sebuah lafazh, namun makna tersebut tidak berada dalam lafazh itu sendiri. Artinya makna yang diperoleh dari sebuah ungkapan lafazh tidak berada dalam pemahaman yang keluar dari lafazh itu sendiri, namun berada dalam pemaknaan yang berada pada pemikiran atas pemahaman lafazh tersebut. Pemahaman atas pemaknaan tersebut yang terdapat dalam mafhum diperoleh setelah adanya rangkaian atas lafazh tersebut. Dalam konteks ini, interpretasi atas makna i'rob dengan pemaknaan secara mafhum diperoleh setelah adanya kesamaan pemaknaan 
di luar apa yang ditunjukkan oleh i'rob itu sendiri yaitu pemaknaan terhadap i'rob dalam konteks kehidupan sehari-hari.

Dalam hubungan dengan tanda-tanda perubahan, pada prinsipnya ada dua tanda yaitu harokat (حركة yang berarti gerakan/pergerakan) dan huruf (حرف yang berarti perbuatan yang memalingkan). Pada dasarnya yang menjadi tanda atas sebuah perubahan adalah harokat (pergerakan) sementara huruf menjadi tanda pengganti, cabang saja. Makna atas hurufhuruf yang menjadi tanda i'rob yaitu wawu, alif, ya', nun.

Berikut peneliti uraikan pembahasan i'rob baik secara gramatikal bahasa Arab dilanjutkan dengan interpretasi atas pemaknannya menggunakan dalalah lafzhiyyah dalam konteks kehidupan sehari-hari.

Perubahan adalah berubahnya akhir الإعراب هو تغيير أواخر الكلم لاختلاف العوامل setiap kalimat (kondisi) karena adanya perbedaan faktor yang الداخلة عليها لفظاً أو تقديراً. mempengaruhinya baik secara lafadz (tampak) ataupun secara perkiraan.

Interpretasi i'rob melahirkan artikulasi makna yaitu bahwa perubahan tidak hanya terjadi dalam kalimat yang disebabkan oleh adanya perubahan faktor yang mempengaruhinya. Perubahan (i'rob) juga terjadi dalam kondisi manusia yang disebabkan oleh perbedaan factor-faktor yang mempengaruhinya. Dalam hal ini, makna kalimat dapat diinterpretasikan realitas manusia yang bisa berubah sesuai dengan faktorfaktor yang melingkupinya.

Pada hakikatnya baik dan buruk semuanya berasal dari Allah25. Namun, dalam tataran realitas kehidupan yang dialami manusia, kebaikan dan keburukan semuanya bergantung pada perilaku manusia itu sendiri. Manusia berbuat baik maka ia akan menjadi derajat yang mulia, sebaliknya manusia berbuat buruk maka ia akan mendapat predikat tercela. 


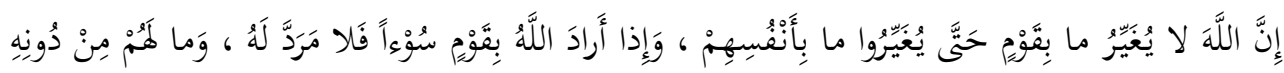

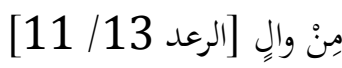

Dengan demikian, Syaikh Wahbah az-Zuhaily menjelaskan bahwa perubahan kondisi manusia ingin berubah menjadi baik ataupun sebaliknya semuanya dapat dilihat dan diperhatikan dari perbuatan manusia itu sendiri²6.

Macam-macam i'rob dibagi menjadi empat yaitu i'rob rofa', nashob, khofadl, jazm. Isim (nama, identitas) dapat

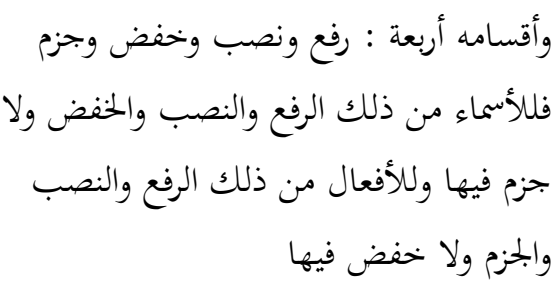
dimasuki i'rob rofa', nashob, dan khofadl, sementara $i^{\prime} r o b$ jazm tidak bisa masuk pada isim. Fi'il (perbuatan) dapat dimasuki i'rob rofa', nashob, dan jazm, sementara $i^{\prime}$ rob khofadl tidak bisa masuk pada fi'il (perbuatan).

Interpretasi macam-macam i'rob melahirkan artikulasi makna yaitu bahwa dalam kehidupan manusia, manusia mempunyai empat status yaitu status jazm (stagnan), khofadl (rendah), nashob (sama, sejajar, standar) dan rofa' (tinggi, terbang). Manusia sebagai sebuah nama, identitas dapat dimasuki oleh tanda-tanda perubahan rofa' (tinggi, terbang), nashob (sama, sejajar, standar) dan khofadl (rendah). Sementara manusia dilihat dari kemungkinan perbuatan yang bisa dilakukannya dapat memiliki kemungkinan tanda-tanda tanda-tanda perubahan rofa' (tinggi, terbang), nashob (sama, sejajar, standar) dan jazm (stagnan).

I'rob rofa' mempunyai empat tanda للرفع أربع علامات : الضمة والواو والألف والنون yaitu dlommah, (huruf) wawu, alif, dan tetapnya nun.

${ }^{26}$ Baca Wahbah bin Musthofa az-Zuhailiy. Tafsir Munir. Maktabah Syamilah (Kitab Digital). Juz 10 hlm 38. 
Interpretasi macam-macam i'rob melahirkan artikulasi makna yaitu seorang manusia dilihat sebagai isim (nama, identitas) ataupun dilihat dari aspek perbuatannya dapat berada pada status tinggi (rofa'). Tanda-tanda seseorang memiliki status tinggi yaitu dlommah (mengumpulkan), wawu, alif dan nun.

Perilaku tanda-tanda $i^{\prime}$ rob rofa' (tinggi, mulia) digambarkan sebagai perilaku yang positif, yang selalu optimis terhadap jalan kebaikan. Mereka yang mempunyai perilaku positif dan optimis, semangat bekerja keras untuk mencapai hasil yang diinginkan. Dalam hal ini Allah menegaskan bahwa siapapun yang berusaha akan mendapat petunjuk untuk meraihnya. Demikian tafsir ayat yang disampaikan oleh Syaikh Muhammad Sayyid Tanthowi dalam Tafir Wasiit lil Qur'an Karim saat menjelaskan ayat ${ }^{27}$

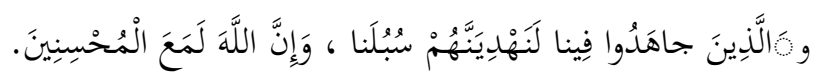

Namun demikian, i'rob rofa' selain bermakna status yang tinggi, i'rob rofa' juga berarti hilang, sia-sia dan tidak bernilai apa-apa. Kondisi rofa' berarti hilang dan tidak bernilai terjadi saat tanda-tanda rofa' justru dilakukan secara berlebihan dan tidak sesuai dengan tujuan semula, yaitu bukan tujuan kebaikan. Hal ini tercermin dari penggalan Surat al-Humazah.

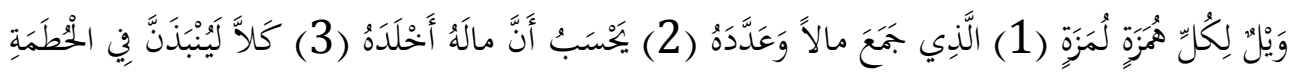

Syaikh Abu Bakar bin Husain bin Umar al-Maraghi menjelaskan bahwa orang-orang yang selalu mengumpulkan harta kekayaan, merasa tidak pernah puas dengan cara selalu menghitung-hitung kekayaannya masuk dalam ancaman yang Allah ${ }^{28}$.

27 Syaikh Muhammad Sayyid Tanthowi. Tafsir Wasiit lil Qur'an Karim. Maktabah Syamilah (Kitab Digital). Juz 11 hlm 58.

28 Syaikh Abu Bakar bin Husain bin Umar al-Maraghi. Tafsir al-Maraghi. Maktabah Syamilah (Kitab Digital). Juz 20 hlm 237. 
I'rob nashob mempunyai lima tanda yaitu fathah, alif, kasroh, ya' dan membuang nun

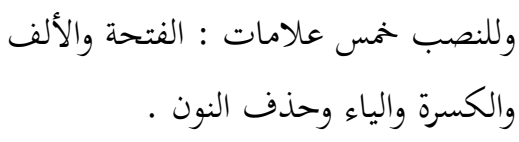

Interpretasi macam-macam i'rob melahirkan artikulasi makna yaitu seorang manusia dilihat sebagai isim (nama, identitas) ataupun dilihat dari aspek perbuatannya dapat berada pada status nashob (sama, sejajar, standar). Tanda-tanda seseorang memiliki status nashob (sama, sejajar, standar) yaitu: fathah, alif, ya', kasroh dan membuang huruf nun.

Perilaku tanda-tanda i'rob nashob (sama, sejajar) digambarkan sebagai perilaku yang terbuka, dan siap membuka diri, memikul bersama dengan komunitasnya. Mereka yang mempunyai perilaku ini siap bersama-sama dengan komunitasnya memikul beban bersama dalam kondisi apapun.

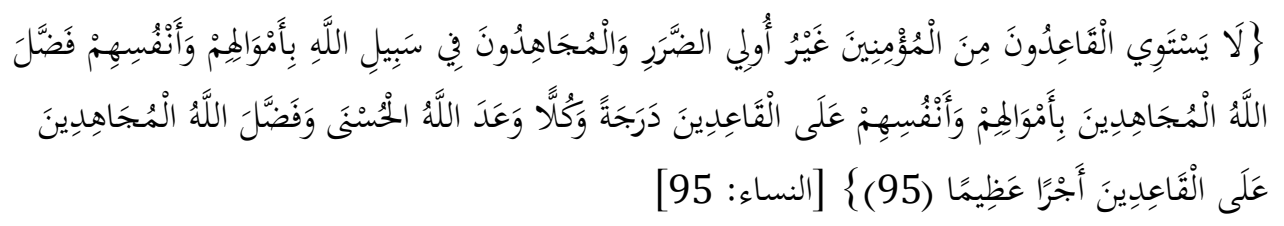

Ketika menjelaskan ayat ini, Syaikh Nashiruddin Abul Khoir Abdullan bin Umar bin Muhammad al-Baidlowi bahwa status orang yang berusaha berjuang dan mereka yang hanya duduk (tidak ikut berjuang) jelas berbeda. Allah memberikan keutamaan baik dari sisi status ataupun juga materiil terhadap mereka yang berusaha dan berjuang29.

I'rob khofadh mempunyai tiga tanda yaitu: kasroh, ya' dan fathah

وللخفض ثلاث علامات : الكسرة والياء والفتحة

Interpretasi macam-macam i'rob melahirkan artikulasi makna yaitu seorang manusia dilihat sebagai isim (nama, identitas) ataupun dilihat dari aspek perbuatannya dapat berada pada status khofadl (rendah). Tandatanda seseorang memiliki status khofadl (rendah) yaitu kasroh, ya' dan fathah.

29 Syaikh Nashiruddin Abul Khoir Abdullan bin Umar bin Muhammad al-Baidlowi. Tafsir al-Baidlowi. Maktabah Syamilah (Kitab Digital). Juzl 1 hlm 488. 
Perilaku tanda-tanda i'rob khofadl (rendah) digambarkan sebagai perilaku yang suka merusak dan suka membuat ulah. Al-Qur'an saat mengisahkan tentang adzab yang menimpa umat-umat terdahulu selalu menyelipkan sebab-sebabnya yaitu umat tersebut selalu membuatkan kerusakan. Salah satunya tentang kaum Madyan dalam ayat berikut.

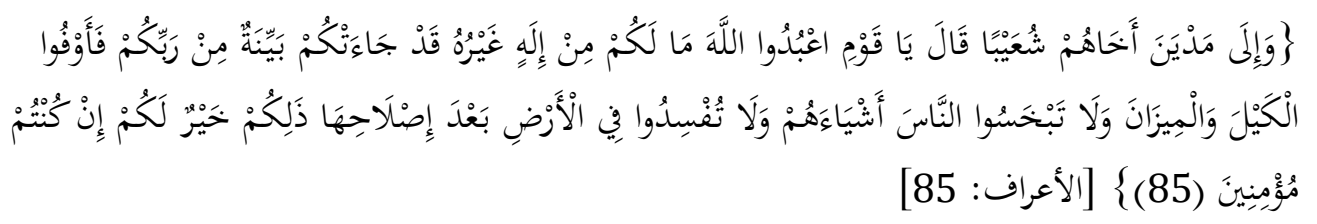

Demikian juga, al-Qur'an juga memperingatkan dampak buruk perilaku manusia yang suka melakukan kerusakan yaitu rusaknya ekosistem dan keseimbangan alam semesta.

\} [الروم:

Saat menjelaskan tentang ayat ini, Syaikh Fakhruddin ar-Rozi menjelaskan bahwa prinsipnya semua kerusakan yang dilakukan oleh manusia bersumber dari sifat syirik (sebagai lawan dari perilaku iman). Perilaku merupakan bentuk syirik kepada Allah dalam bentuk perbuatan, yaitu perbuatan durhaka dan maksiat kepada Allah. Orang yang suka membuat kerusakan dan suka berbuat dosa pada dasarnya manusia tersebut berbuat syirik melalui perbuatannya (sebagai kebalikan dari perbuatan iman) $)^{30}$.

Jazm mempunyai dua tanda yaitu وللجزم علامتان : السكون والحذف . sukun dan membuang nun

30 Syaikh Abu Abdillah Muhammad bin Umar bin Hasan bin Husain Fakhruddin arRozi. Mafatihul Al-Ghoib Tafsir ar-Rozi. Maktabah Syamilah (Kitab Digital). Juz 12 hlm 246. 
Interpretasi macam-macam i'rob melahirkan artikulasi makna yaitu seorang manusia dilihat sebagai dari aspek perbuatannya dapat berada pada status jazm (tetap, stagnan). Tanda-tanda seseorang memiliki status jazm (stagnan) yaitu sukun (diam) dan membuang nun. Perilaku tandatanda i'rob khofadl (rendah) digambarkan sebagai perilaku yang diam, tidak bisa berbuat apa-apa. Perilaku diibaratkan seperti bayi yang masih berada dalam kandungan.

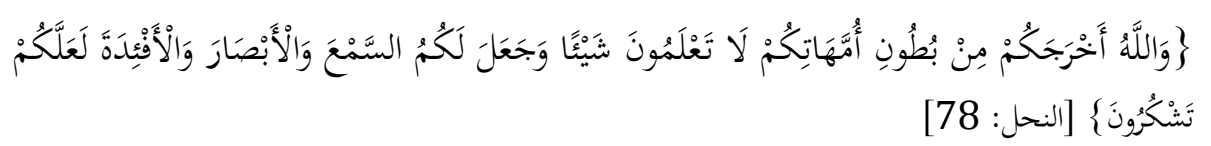

Manusia yang berada dalam kandungan tidak bisa berbuat apa-apa. Saat berada dalam rahim ibu, sang bayi telah ada, namun dianggap tidak ada (وجوده كعدمه). Bayi hanya diam tidak bisa melakukan apa-apa. Manusia yang dalam kehidupannya hanya diam, maka keberadaanya diibaratkan dengan bayi, keberadaannya dianggap tidak ada, karena tidak berdampak apa-apa terhadap kebaikan ataupun keburukan sekalipun. Dengan demikian, i'rob jazm berada di bawah i'rob khofadl dengan sudut pandang bahwa perilaku merusak yang menyebabkan khofadl dapat menimbulkan reaksi kebalikan berupa respon kebaikan dari orang-orang baik dan orangorang hendak memperbaikinya.

\section{Penutup}

Sebuah bahasa dapat mengungkapkan rahasia yang tersembunyi dalam kehidupan. Dalam gramatika ilmu bahasa, ilmu nahwu adalah sebuah ilmu yang mempelajari gramatika bahasa Arab. Jika disederhanakan ilmu nahwu adalah ilmu yang mempelajari tentang bagaimana membaca, merangkai, menyusun bahasa Arab. Bagi kalangan pesantren, ilmu nahwu terutama kitab al-Jurumiyah dipakai sebagai ilmu untuk mengantarkan santri bisa membaca kitab kuning. Lebih dari itu, menggunakan kajian semantik leksikal, ilmu nahwu dapat diartikulasikan sebagai ilmu tentang contoh-contoh dalam kehidupan sehari-hari, sesuai dengan namanya, ilmu nahwu adalah ilmu contoh. Demikian halnya, salah satu bagian dari ilmu nahwu yaitu bab tentang $i^{\prime} r o b$. 
I'rob dapat diartikulasikan dalam makna kehidupan sehari, berikut dengan tanda-tanda i'robnya. I'rob jazm berarti konstan dan diam yang memiliki tanda i'rob sukun (diam); artinya seseorang yang hanya diam, berpangku tangan (sukun/diam) maka statusnya akan stagnan. I'rob khofazh (rendah, Jar; menarik) berarti rendah memiliki tand i'rob kasroh (mematahkan, merusak), artinya seseorang yang pekerjaan identik dengan merusak dan mematahkan maka statusnya akan berada pada status rendah (bawah). I'rob nashob berarti sama, standar, rata yang memiliki tanda fathah (membuka); artinya seseorang yang mempunyai perilaku fathah (membuka) maka statusnya akan sama, sederajat dengan orang kebanyakan. I'rob rofa' berarti tinggi, terbang, hilang memiliki tanda i'rob dlommah (mengumupulkan); artinya seseorang yang berkeinginan berada pada posisi rofa' (tinggi dan terbang) maka ia harus memiliki perilaku dlommah; yaitu perilaku mengumpulkan, yaitu: mengumpulkan ilmu pengetahuan, teman, relasi, kerjasama, pengikut, termasuk juga harta dan jabatan. Dengan demikian, seseorang dapat memiliki derajat yang tinggi. 


\section{DAFTAR PUSTAKA}

Baidlowi, Syaikh Nashiruddin Abul Khoir Abdullan bin Umar bin Muhammad al-. Tafsir al-Baidlowi. Maktabah Syamilah (Kitab Digital).

Imrithy, Syaikh Syafifuddin Yahya al-. Nazham al-Jurumiyah al-Imrithy. Maktabah Syamilah (Kitab Digital). Shonhaji, Abu Abdillah Muhammad bin Muhammad bin Dawud Ash-. Matn alAjurumiyah. Maktabah Syamilah.

Maraghi, Syaikh Abu Bakar bin Husain bin Umar al-. Tafsir al-Maraghi. Maktabah Syamilah (Kitab Digital).

Rozi,Syaikh Abu Abdillah Muhammad bin Umar bin Hasan bin Husain Fakhruddin ar-. Mafatihul Al-Ghoib Tafsir ar-Rozi. Maktabah Syamilah (Kitab Digital).

Zuhailiy, Wahbah bin Musthofa az-. Tafsir Munir. Maktabah Syamilah (Kitab Digital). Tanthowi, Syaikh Muhammad Sayyid. Tafsir Wasiit lil Qur'an Karim. Maktabah Syamilah (Kitab Digital). 